\title{
Qualidade do leite ofertado a bezerros de propriedades leiteiras na região do norte do Paraná
}

Enrico Nogueira Tozzi, Ana Silvia Soubhia, Ana Flávia Danulussi Feitoza, Ana Carolina Pires de Campos, Éder Paulo Fagan, Francielle Gibson Zacarias, Francisco Armando de Azevedo Souza, Thais Helena Constantino Patelli

Universidade Estadual do Norte do Paraná (UENP), Bandeirantes, PR, Brasil

*Autor correspondente

e-mail: anasilvia_soubhia@hotmail.com

\section{Resumo}

Sendo o leite o primeiro alimento do bezerro e sua única fonte de nutrientes até que seu sistema digestório possa metabolizar outros alimentos, a qualidade ofertada aos bezerros nesse período pré-ruminal é de fundamental importância para o seu desenvolvimento, produtividade e longevidade. Este trabalho teve como objetivo avaliar a qualidade do leite que tem sido oferecido aos bezerros de propriedades leiteiras na região Norte Pioneiro do Paraná. Amostras de leite foram colhidas de 47 propriedades destinadas à produção de leite, localizadas na região Norte Pioneiro do Paraná, realizadas no período da manhã antes do fornecimento de leite aos bezerros, entre dezembro de 2014 a fevereiro de 2015 . 0 leite foi colhido diretamente do recipiente no qual era armazenado utilizando-se concha de metal flambada, colocado em frasco de vidro estéril com capacidade para $200 \mathrm{~mL}$ e acondicionado em caixa isotérmica até o laboratório de análise. Foram realizadas as seguintes análises: contagem Padrão em Placas (CPP), contagem de Número Mais Provável - NMP de coliformes à $30^{\circ} \mathrm{C}$, termotolerantes à $45^{\circ} \mathrm{C}$ e identificação de Escherichia coli. Para a CPP, utilizou-se diluição seriada das amostras em solução salina peptonada e semeada em placas de petri estéreis. Uma alíquota de $1 \mathrm{~mL}$ de cada diluição leite:salina (amostra integral, $10^{-1}$ e $10^{-2}$ ) foi adicionada em tubos com $9 \mathrm{~mL}$ de caldo verde para contagem de coliformes à $30^{\circ} \mathrm{C}$. Os tubos foram incubados em estufa a $35^{\circ} \mathrm{C}$ por 48 horas até leitura. Amostras com presença de gás no tubo de Durham foram passadas para tubos com caldo EC (Escherichia coli) para detecção de coliformes termotolerantes e incubadas em estufa a $45^{\circ} \mathrm{C}$ por 48 horas. Das 47 propriedades, 27,66\% apresentaram Contagem Padrão em Placas (CPP) acima do permitido pela Instrução Normativa $\mathrm{N}^{\circ} 62$ de 2011, a qual preconiza valores de até 300 mil UFC/mL. Valores acima do permitido são indicativos de deficiência na limpeza e higienização dos equipamentos de ordenha, do sistema de refrigeração, da glândula mamária e também da presença de mastite. Com relação ao grupo dos coliformes, 65,96\% e 38,30\% do leite das propriedades leiteiras apresentaram Coliformes à $30^{\circ} \mathrm{C}$ e 
$45^{\circ} \mathrm{C}$, respectivamente, acima de $110 \mathrm{NMP} / \mathrm{mL}$, enquanto que a Escherichia coli foi identificada em $42,55 \%$ das amostras de leite. A presença em grande número desses agentes indica uma possível contaminação de origem fecal, assim como eventual ocorrência de enteropatógenos. Com altos valores de CPP, toxinas e/ ou microorganismos patogênicos podem ser excretados no leite afetando diretamente a saúde do bezerro. Concluiu-se, portanto, que a qualidade do leite ofertado aos bezerros nas propriedades avaliadas é baixa, podendo ser considerado risco em potencial à saúde desses animais em crescimento. 